\title{
PENGEMBANGAN SILABUS DAN RENCANA PELAKSANAAN PEMBELAJARAN AGAMA HINDU DI SMA
}

\author{
I Nengah Dugdug \\ SMA (SLUA) Saraswati Denpasar
}

\begin{abstract}
The implementation of Hindu education in 1994 was still dominated by cognitive achievement rather than affective and psychomotor ability in learning objectives. In 2003 The National Education Department through National Education Standard Institution comprised national competency-based curriculum for Hindu subject. Competency-based Curriculum in Senior High School level needs further improvement through educational unit level curriculum because it will improve human sources quality especially teacher in developing syllabi and lesson plan. Based on the above fact, the writer formulates three problems as follows: (1) what are the steps of developing syllabus and lesson plan in Senior High School; (2) what are the factors that may affect the process of developing Hindu subject syllabus and lesson plan in Senior High School; (3) What efforts are needed in developing Hindu subject syllabus and lesson plan in Senior High School. The steps of developing Hindu subject syllabus and lesson plan can be independently or collaboratively in deliberation of subject teacher. The factors that encourage the development of the syllabus and lesson plan, that is, interest to the duties, responsibilities of the task, learning facilities, the attention of the head master, community demand and teachers' administrative demand. These efforts which were done in developing syllabus and lesson plan was discussion, following seminar, workshop, and upgrading program as well as providing facilities and infrastructures. The Hindu Subject syllabus and lesson plan are expected to be applied in Senior High School.
\end{abstract}

Keywords: syllabus, lesson plan, Hindu.

\section{PENDAHULUAN}

Secara kronologis kurikulum tahun 1978, 1984, dan tahun 1994 kurang mengetengahkan acuan standar yang lebih jelas tentang kemampuan yang harus dikembangkan pada peserta didik. Kurikulum pendidikan Agama Hindu tahun 1994 telah mempertimbangkan kemampuan afektif dan psikomotor dalam rumusan tujuan pembelajaran. Implementasinya dirasakan masih terasa didominasi pencapaian kognitif dari pada psikomotor, dan afektif. Kurikulum pendidikan Agama Hindu tahun 1994 kurang mengakomodasi keragaman kebutuhan daerah. Penjabaran pelajaran Agama Hindu banyak diluar jangkauan manusia, akibatnya pelajaran Agama Hindu sulit untuk diserap dan dimengerti oleh siswa. Atas dasar tersebut 
maka tahun 2003 disusun kurikulum nasional pendidikan Agama Hindu yang berbasis pada kompetensi yang ditandai dengan ciri-ciri antara lain : 1) lebih menitikberatkan target pencapaian kompetensi dari pada penguasaan materi, 2) mengakomodasi keragaman kebutuhan dan sumber daya pendidikan yang tersedia, 3) memberikan kebebasan yang lebih luas kepada pelaksana pendidikan yang mengembangkan dan melaksanakan program pembelajaran sesuai dengan kebutuhan daerah (Depdiknas, 2003:1).

Peraturan Pemerintah Republik Indonesia nomor 19 tahun 2005 pasal 20 dinyatakan perencanaan proses pembelajaran yang memuat sekurang-kurangnya tujuan pembelajaran, materi ajar, metode ajar, metode pengajaran, sumber belajar, dan penilaian hasil belajar (SNP, 2007:13).

Dalam pernyataan tersebut, guru dalam proses pembelajaran Agama Hindu hendaknya mampu mengembangkan silabus dan Rencana Pelaksanaan Pembelajaran Agama Hindu. Namun kenyataannya di berbagai sekolah banyak guru belum mampu mengembangkan silabus, dan Rencana Pelaksanaan Pembelajaran meskipun telah menerapkan KTSP.

Pandangan masyarakat terhadap pengembangan silabus, dan Rencana Pelaksanaan Pembelajaran Agama Hindu di sekolah, selama ini adalah belum adanya keseimbangan dengan prilaku yang dikehendaki oleh masyarakat.

Tuntutan masyarakat global terhadap pengembangan silabus, Rencana Pelaksanaan Pembelajaran Agama Hindu mampu menghasilkan keseimbangan antara pengetahuan teoritis dengan pengetahuan prakris yakni apa yang diajarkan di sekolah ada relevansinya dengan kehidupan nyata setelah peserta didik terjun ke masyarakat. Pengembangan silabus dan Rencana Pelaksanaan Pembelajaran Agama Hindu disekolah bertujuan untuk menumbuhkan dan meningkatkan Sradha peserta didik kehadapan Brahman melalui penghayatan dan pengamalan ajaran Agama, menjadi Hindu yang dharmika dan mampu mewujudkan cita-cita luhur Moksrtham Jagadhita (Depdiknas, 2003:6). Orang tua siswa sangat mengharapkan agar anaknya setelah tamat dapat menjadi primer-primer pembangunan atas dasar konsep yang tangguh dan dapat bekerja secara profesional serta mampu menerapkan ajaran Tri Kaya Parisudha yaitu manacika (berpikir), wacika (berkata), dan kayika (berbuat). 
Pengembangan silabus, dan Rencana Pelaksanaan Pembelajaran Agama Hindu adalah usaha yang dilakukan secara terencana dan berkesinambungan dalam rangka mengembangkan kemampuan peserta didik untuk memperteguh keimanan dan bhakti kepada Tuhan yang Maha Esa, berakhlak mulia, serta dapat meningkatkan potensi spiritual sesuai dengan ajaran Agama.

\section{PEMBAHASAN}

\section{Langkah-langkah Pengembangan Silabus}

Pengembangan Silabus dilakukan secara sistematis, dan mencakup komponen-komponen yang saling berkaitan untuk mencapaai kompetensi dasar yang telah ditetapkan. Dalam Kurikulum Tingkat Satuan Pendidikan (KTSP), Silabus merupakan penjabaran standar Kompetensi dan kompetensi dasar kedalam materi pembelajaran, kegiatan pembelajaran, dan indikator pencapaian kompetensi untuk penilaian hasil belajar(Mulyasa, 2007:190)

Badan Standar Nasional Pendidikan (BSNP) menyebutkan silabus adalah rencana pembelajaran pada suatu dan kelompok mata pelajaran/tema tertentu yang mencakup Standar Kompetensi, Kompetensi dasar, materi pokok/pembelajaran, kegiatan pembelajaran, indikator pencapaian kompetensi untuk penilaian, alokasi waktu, dan sumber belajar (BSNP, 2006:14).

Dalam Kurikulum Tingkat Satuan Pendidikan (KTSP) Pengembangan silabus diserahkan sepenuhnya kepada sekolah atau satuan pendidikan (Mulyasa, 2007:191). Setiap satuan pendidikan atau sekolah diberikan kebebasan, keleluasaan dalam mengembangkan silabus sesuai dengan kondisi dan karakteristik sekolah masingmasing dengan mengacu pada kurikulum nasional atu standar nasional.

Langkah-langkah pengembangan silabus dalam Kurikulum Tingkat Satuan Pendidikan (KTSP) adalah sebagai berikut :

1. Mengkaji Standar Kompetensi dan Kompetensi dasar mata pelajaran sebagaimana tercantum pada standar isi dengan memperhatikan :

a. Urutan berdasarkan hierarki konsep disiplin ilmu atau tingkat kesulitan Materi.

b. Keterkaitan antara standar kompetensi dan kompetensi dasar dalam mata Pelajaran 
c. Keterkaitan antara standar kompetensi dan kompetensi dasar antar mata pelajaran.

2. Mengidentifikasi materi pokok. pembelajaran yang menunjang pencapaian kompetensi dasar dengan mempertimbangkan :

a. Potensi potensi peserta didik.

b. Relevansi dengan karakteristik daerah.

c. Tingkat perkembangan fisik, intelektual, emosional, sosial, dan

d. spiritual peserta didik.

e. Kebermanfaatan bagi peserta didik.

f. Struktur keilmuwan.

g. Aktualitas, kedalaman, dan keluasan materi pembelajaran.

h. Relevansi dengan kebutuhan peserta didik, tuntutan lingkungan dan, alokasi waktu.

3. Mengembangkan kegiatan pembelajaran dirancang untuk memberikan pengalaman belajar yang melibatkan proses mental dan fisik melalui interaksi antar peserta didik, peserta didik dengan guru, lingkungan, dan sumber belajar lainnya dalam rangka pencapaian kompetensi dasar. Pengalaman belajar yang dimaksud dapat terwujud melalui penggunaan pendekatan pembelajaran yang bervariasi dan berpusat pada peserta didik. Pengalaman belajar memuat kecakapan hidup yang perlu dikuasai peserta didik. Hal - hal yang harus diperhatikan dalam mengembangkan kegiatan pembelajaran adalah sebagai berikut : a) kegiatan pembelajaran disusun untuk memberikan bantuan kepada para pendidik, khususnya guru agar dapat melaksanakan proses pembelajaran secara professional, b) kegiatan pembelajaran memuat rangkaian kegiatan yang harus dilakukan oleh peserta didik secara berurutan untuk mencapai kompetensi dasar, c) penentuan urutan kegiatan pembelajaran harus sesuai dengan hierarki konsep materi pembelajaran, d) rumusan pernyataan dalam kegiatan pembelajaran minimal mengandung dua unsur yang mencerminkan pengelolaan pengalaman belajar siswa yaitu kegiatan siswa dan materi.

4. Merumuskan indikator pencapaian kompetensi. 
Indikator merupakan indikasi pencapaian kompetensi dasar. Pencapaian kompetensi dasar ditandai dengan perubahan perilaku yang terukur yang mencakup sikap, pengetahuan dan ketrampilan. Indikator dikembangkan sesuai dengan karakteristik peserta didik, mata pelajaran, satuan pendidikan, potensi daerah. Indikator dirumuskan dalam kata kerja operasionalyang terukur dan atau dapat diobservasi. Indikator digunakan sebagai dasar untuk menyusun alat penilaian.

5. Penentuan jenis penilaian pencapaian kompetensi dasar peserta didik dilakukan berdasarkan indikator.

Penilaian dilakukan dengan menggunakan tes dan non tes dalam bentuk tertulis, lisan, pengamatan kinerja, pengukuran sikap, penilaian hasil karya berupa tugas proyek dan produk, penggunaan portopolio, dan penilaian diri. Penilaian merupakan serangkaian kegiatan untuk memperoleh, menganalisis, dan menafsirkan data tentang proses dan hasil belajar peserta didik yang dilakukan secara sistematis dan berkeseinambungan. Penilaian memberi informasi yang bermakna dalam pengambilan keputusan. Hal-hal yang perlu diperhatikan dalam penilaian :

a. Penilaian diarahkan untuk mengukur pencapaian kompetensi.

b. Penilaian menggunakan acuan kriteria yaitu berdasarkan apa yang bisa dilakukan peserta didik setelah mengikuti proses pembelajaran dan bukan menentukan posisi seseorang terhadap kelompoknya.

c. Sistem yang direncanakan adalah sistem penilaian yang berkelanjutan. Berkelanjutan dalam arti semua indikator ditagih, kemudian hasilnya dianalisis untuk menentukan kompetensi dasar yang telah dimiliki dan yang belum serta untuk mengetahui kesulitan siswa.

d. Hasil penilaian dianalisis untuk menentukan tindak lanjut. Tindak lanjut tersebut berupa perbaikan proses pembelajaran berikutnya, program remidi bagi peserta didik yang memilih kompetensi dibawah kriteria ketuntasan, dan program pengayaan bagi peserta didik yang telah memenuhi kriteria ketuntasan. 
e. Sistem penilaian harus disesuaikan dengan pengalaman belajar yang ditempuh dalam proses pembelajaran. Misalnya, jika pembelajaran menggunakan pendekatan tugas observasi lapangan maka evaluasi dalam bentuk keterampilan proses, mencari informasi di lapangan dengan teknik wawancara atau observasi.

6. Menentukan alokasi waktu pada setiap kompetensi dasar.

Penentuan alokasi waktu didasarkan pada jumlah minggu efektif dan waktu yang diperoleh untuk setiap mata pelajaran perminggu dengan mempertimbangkan jumlah kompetensi dasar, keluasan, kedalaman, tingkat kesulitan, dan tingkat kepentingan kompetensi dasar. Alokasi waktu yang dicantumkan dalam silabus merupakan perkiraan waktu untuk kompetensi dasar yang dibutuhkan oleh peserta didik dengan kemampuan yang beragama.

7. Menentukan rujukan, objek, dan bahan sebagai sumber belajar dalam Kegiatan pembelajaran.

Sumber belajar yang berupa media cetak dan elektronik, narasumber, serta lingkungan fisik, alam, sosial dan budaya. Penentuan sumber belajar didasarkan pada standar kompetensi dan kompetensi dasar serta materi pokok/ pembelajaran dan indikator pencapaian kompetensi (BSNP, 2006:12).

\section{Langkah-langkah Pengembangan Rencana Pelaksanaan Pembelajaran}

Rencana pelaksanaan pembelajaran adalah rencana yang menggambarkan prosedur dan manajemen pembelajaran untuk mencapai satu atau lebih kompetensi yang ditetapkan dalam standar isi dan dijabarkan dalam silabus. Rencana Pelaksanaan Pembelajaran merupakan komponen yang paling penting dalam Kurikulum Tingkat Satuan Pendidikan. Terkait dengan pengembangan Rencana Pelaksanaan Pembelajaran tugas guru dalam kurikulum yang berbasis KTSP adalah menjabarkan silabus ke dalam Rencana Pelaksanaan Pembelajaran yang lebih operasional dan rinci dalam pembelajaran.

Dalam pengembangan Rencana Pelaksanaan Pembelajaran, guru diberi kebebasan untuk mengubah, memodifikasi, dan menyesuaikan silabus dengan kondisi sekolah dan daerah serta karakteristik peserta didik (Mulyasa, 2007:212).

Menurut Mulyasa (2007:324) langkah-langkah yang patut dilakukan guru dalam penyusunan Rencana Pelaksanaan Pembelajaran yaitu : langkah pertama, 
mengidentifikasi dan mengelompokkan kompetensi yang ingin dicapai setelah proses pembelajaran. Kompetensi yang dikembangkan harus mengandung muatan yang menjadi materi standar yang dapat diidentifikasi berdasarkan kebutuhan peserta didik, kebutuhan masyarakat, ilmu pengetahuan, dan filsafat. Untuk mengidentifikasikan kompetensi harus memperhatikan unsur proses pengatur nyata dan mengandung pengalaman belajar yang diperlukan untuk mencapai kompetensi tersebut. Pembentukan kompetensi sering kali membutuhkan waktu relatif lama, realistis, dan dapat dimaknai sebagai kegiatan atau pengalaman belajar tertentu serta komprehensif, artinya berkaitan dengan visi dan misi sekolah.

Langkah kedua adalah mengembangkan materi standar yang merupakan isi kurikulum yang diberikan kepada peserta didik dalam proses pembelajaran dan pembentukan kompetensi. Materi standar mencakup tiga komponen utama, yaitu ilmu pengetahuan, proses, dan nilai-nilai. Tiga komponen utama tersebut dapat dirinci sesuai dengan kompetensi dasar visi dan misi sekolah. Sehubungan dengan itu guru sebagai manajer kurikulum di Sekolah dapat memilih dan mengembangkan materi standar sesuai dengan kebutuhan, perkembangan jaman, minat, kemampuan, dan perkembangan peserta didik.

Langkah ketiga adalah menentukan metode dalam menyusun Rencana Pelaksanaan Pembelajaran (RPP). Penentuan metode pembelajaran ada kaitan dengan pemilihan strategi pembelajaran yang paling efisien dan efektif dalam memberikan pengalaman belajar yang diperlukan untuk membentuk kompetensi dasar. Strategi pembelajaran merupakan kegiatan guru dalam melakukan proses pembelajaran dan pembentukan kompetensi. Strategi pembelajaran dapat memberikan kemudahan kepada peserta didik untuk mencapai tujuan. Setiap pembelajaran dan pembentukan kompetensi. Guru dapat menggunakan berbagai metode, dan berbagai media untuk mencapai tujuan pembelajaran. Dalam hal ini guru dapat memilih dan menggunakan berbagai metode dan media pembelajaran yang dapat menumbuhkan aktivitas dan kreatifitas peserta didik.

Langkah keempat pengembangan Rencana Pelaksanaan Pembelajaran adalah merencanakan penilaian. Sejalan dengan KTSP yang berbasis kompetensi penilaian hendaknya dilakukan berdasarkan apa yang dilakukan oleh peserta didik selama proses pembelajaran dan pembentukan kompetensi. Oleh karena itu, penilaian 
hendaknya dilakukan berbasis kelas (PBK) dan ujian dilakukan berbasis sekolah. Penilaian pembelajaran dilakukan untuk mengetahui tercapai tidaknya pelaksanaan pembelajaran. Penilaian pembelajaran mencakup semua komponen pembelajaran, yaitu baik proses maupun hasilnya. Untuk itu, kegiatan penilaian membutuhkan alat penilaian dalam mencapai tujuan, dan guru perlu menentukan alat penilaian sesuai dengan kompetensi yang dinilai.

\section{Faktor-faktor Pendorong dalam Pengembangan Silabus dan Rencana Pelaksanaan Pembelajaran}

Faktor-faktor yang mendorong dalam pengembangan Silabus dan Rencana Pelaksanaan Pembelajaran Agama Hindu dapat dipilih-pilih menjadi enam faktor yaitu : minat terhadap tugas, tanggung jawab terhadap tugas, sarana dan prasarana, perhatian dari Kepala Sekolah, tuntutan masyarakat, dan tuntutan administrasi guru.

\section{Minat Terhadap Tugas}

Menurut Slameto (2003:37) menyebutkan minat adalah kecenderungan yang tetap untuk memperhatikan dan mengenang beberapa kegiatan. Demikian pula minat adalah suatu rasa lebih suka dan rasa keterkaitan pada suatu hal aktifitas tanpa ada yang menyuruh. Sedangkan Nawawi dalam Mulyasa (2007:230) mengungkapkan minat dan kemampuan terhadap suatu pekerjaan berpengaruh terhadap moral kerja. Minat merupakan dorongan untuk memilih suatu obyek berupa kegiatan atau pekerjaan yang diekspresikan dengan perasaan suka. Guru dalam mengembangkan Silabus dan Rencana Pelaksanaan Pembelajaran Agama Hindu di sekolah tentu dipengaruhi oleh minat yang ada dalam dirinya. Jika guru mempunyai minat sesuai dengan peranannya, maka guru akan berusaha melakukan tugas-tugas yang berkaitan dengan upaya pengembangan Silabus dan Rencana Pelaksanaan Pembelajaran secara optimal. Faktor minat dapat mendorong untuk menjadikan sikap profesional guru.

Sikap profesional guru dalam pengembangan Silabus dan Rencana Pelaksanaan Pembelajaran yaitu : a) sukarela, b) dapat menyesuaikan diri dan sabar, c) memiliki sikap yang konstruktif dan rasa tanggung jawab, d) berkemauan untuk melatih diri, dan e) memberikan semangat untuk memberikan layanan kepada Sekolah dan masyarakat. 


\section{Tanggung Jawab Terhadap Tugas}

Guru memiliki tanggung jawab terhadap sejumlah tugas yang harus dilakukan sesuai dengan profesinya. Berat ringannya beban, tugas guru akan mempengaruhi usaha-usahanya dalam bekerja sesuai kemampuannya, serta berkaitan dengan kuantitas dan kualitas tugas yang dikerjakannya. Pemberian tanggung jawab secara individual, merupakan kesempatan bagi guru untuk mengoptimalkan segenap potensi yang dimiliki dengan kegiatan pengembangan Silabus dan Rencana Pelaksanaan Pembelajaran.

Tanggung jawab merupakan tuntutan dalam melaksanakan tugas dan kewajiban, sehingga guru yang bertanggung jawab akan berusaha melaksanakan tugas dan kewajibannya dengan baik. Dalam kaitannya dengan pengembangan Silabus dan Rencana Pelaksanaan Pembelajaran untuk menyukseskan implementasi KTSP. Sujana dalam Mulyasa (2007:229) mengungkapkan, bahwa tanggung jawab mengembangkan kurikulum mengandung arti guru dituntut untuk selalu mencari gagasan baru, dan menyempurnakan praktek pembelajaran. Guru dalam mengembangkan Silabus dan Rencana Pelaksanaan Pembelajaran dipengaruhi oleh beban tugas yang menjadi tanggung jawab yang harus dilaksanakan guru dalam kegiatan sehari-hari. Beban tugas dalam pengembangan Silabus dan Rencana Pelaksanaan Pembelajaran terkait dengan peran guru sebagai fasilitator yang memberikan kemudahan belajar kepada peserta didik, melalui kegiatan mengajar, membimbing dan melaksanakan administrasi sekolah.

\section{Sarana dan Prasarana Pembelajaran}

Sarana dan prasarana merupakan alat bantu untuk memudahkan guru dalam pengembangan silabus dan RPP. Sarana pembelajaran meliputi buku pelajaran, buku bacaan, alat, dan berbagai media pengajaran yang lain. Sedangkan prasarana pembelajaran meliputi gedung sekolah, ruang belajar, dan ruang kesenian. (Dimyati dan Mudjiono, 2006:249).

Dalam Peraturan Pemerintah Republik Indonesia nomor 19 tahun 2005 Tentang Standar Nasional Pendidikan pada bab VII pasal 42 ayat 1 dan 2 menyebutkan: (1) setiap satuan pendidikan wajib memiliki sarana yang meliputi perabot, peralatan pendidikan, media pendidikan, buku dan sumber belajar lainnya, 
bahan habis pakai serta perlengkapan lain diperlukan untuk menunjang proses pembelajaran yang teratur dan berkelanjutan, dan (2) setiap satuan pendidikan wajib memiliki prasarana yang meliputi lahan, ruang kelas, ruang pimpinan satuan pendidikan, ruang pendidik, ruang tata usaha, ruang perpustakaan, ruang laboratorium, ruang bengkel kerja, ruang unit produksi, ruang kantin, instalasi daya dan jasa, tempat berolahraga, tempat beribadah, tempat bermain, tempat berekreasi dan ruang /tempat lain yang diperlukan untuk menunjang proses pembelajaran yang teratur dan berkelanjutan.

Dalam pengembangan Silabus dan Rencana Pelaksanaan Pembelajaran agama Hindu sarana dan prasarana tetap diperlukan dan memegang peranan penting. Perlengkapan sarana dan prasarana diperlukan untuk dapat menciptakan sekolah yang bersih rapi, indah dan kondisi yang menyenangkan baik bagi guru dan murid. Hafidz dalam Muhammad Joko Susilo (2007) menyebutkan sarana pendidikan adalah peralatan dan perlengkapan secara langsung dipergunakan dalam menunjang proses pendidikan khususnya dalam pengembangan Silabus dan Rencana Pelaksanaan Pembelajaran.

\section{Perhatian dari Kepala Sekolah}

Menurut Gazali dalam Slameto (2003:56) menyebutkan perhatian adalah keaktifan jiwa yang tertuju kepada suatu obyek. Perhatian kepala sekolah terhadap guru sangat penting untuk meningkatkan profesionalisme kinerja guru (Mulyasa, 2007:234).

Perhatian dari Kepala Sekolah terhadap guru sangat diperlukan untuk memotivasi kinerja guru terkait dengan pengembangan Silabus dan Rencana Pelaksanaan Pembelajaran. Kepala Sekolah memfasilitasi guru dengan menyediakan layanan perpustakaan dan memberikan kepada guru untuk mengikuti pelatihan, workshop, dan penataran. Profesional guru dalam pengembangan silabus dan Rencana Pelaksanaan Pembelajaran diperlukan kecermatan untuk menentukan langkah sabar, ulet, telaten, serta tanggap setiap kondisi sehingga akan membuahkan suatu hasil yang memuaskan. 


\section{Tuntutan Masyarakat}

Pengembangan Silabus dan Rencana Pelaksanaan Pembelajaran Agama Hindu di kembangkan untuk memenuhi kebutuhan masyarakat. Masyarakat yang ada di sekitar Sekolah merupakan masyarakat homogen atau heterogen. Masyarakat belajar, petani, pedagang, dan pegawai. Sekolah melayani aspirasi-aspirasi yang ada dimasyarakat. Perkembangan dunia usaha yang ada dimasyarakat mempengaruhi pengembangan kurikulum khususnya pengembangan Silabus dan Rencana Pelaksanaan Pembelajaran, karena sekolah mempersiapkan peserta didik untuk bekerja dan berusaha. Jenis pekerjaan yang ada dimasyarakat menuntut persiapan di Sekolah. Pengembangan silabus dan Rencana Pelaksanaan Pembelajaran Agama Hindu adalah untuk memenuhi kebutuhan masyarakat (Nana Syaodih Sukmadianata, 2006:159).

Pada dasarnya pengembangan silabus dan Rencana Pelaksanaan Pembelajaran memberi berbagai pengaruh positif dari luar atau dari peserta didik dapat menghadapi masa depannya dengan baik. Dengan demikian, peserta didik diharapkan dapat mengantisipasi perubahan masyarakat agraris ke industri, pengembangan IPTEK, pengangguran intelek, terbatasnya lapangan pekerjaan, masyarakat yang kompleks tetapi bersifat individualistis, pengaruh globalisasi, dan adanya revolusi atau reformasi (Dakir, 2004:84).

\section{Tuntutan Administrasi Guru}

Sebagai administrator pendidikan sebenarnya guru secara terus menerus terlibat dalam pengembangan silabus dan Rencana Pelaksanaan Pembelajaran. Guru memegang peranan penting dalam proses pembelajaran pada sistem dan proses pendidikan. Karena siswa tidak mungkin bisa belajar sendiri tanpa bimbingan guru, maka guru berkewajiban mengembangkan tujuan-tujuan pendidikan menjadi rencana-rencana yang operasional.

Peraturan Pemerintah Republik Indonesia nomor 19 tahun 2005 tentang standar nasional pendidikan pasal 20 menyebutkan perencanaan proses pembelajaran yang memuat sekurang-kurangnya tujuan pembelajaran, materi ajar, metode pengajaran, sumber belajar, dan penilaian hasil belajar (Standar Nasional Pendidikan, 2006:13). 
Guru sebagai pendidik profesional, bukan saja dituntut melaksanakan tugasnya sebagai pengajar, tetapi juga harus memiliki pengetahuan dan kemampuan dalam mengembangkan Silabus dan Rencana Pelaksanaan Pembelajaran.

\section{Upaya-upaya Pengembangan Silabus dan Rencana Pelaksanaan Pembelajaran}

\section{Agama Hindu.}

Upaya-upaya yang dapat dilakukan dalam pengembangan Silabus dan Rencana Pelaksanaan Pembelajaran adalah 1) melakukan diskusi, 2) mengikuti pelatihan, 3) menyediakan sarana dan prasarana.

\section{Melakukan Diskusi}

Diskusi merupakan komunikasi seseorang berbicara satu dengan yang lain, saling berbagi gagasan dan pendapat. Kamus Bahasa Indonesia menyebutkan diskusi yaitu melibatkan orang saling tukar pendapat secara lisan, teratur, dan untuk mengekspresikan pikiran tentang pokok pembicaraan tertentu (Trianto, 2007:117).

Menurut Suryosubroto dalam Trianto (1997:179) diskusi adalah suatu percakapan ilmiah oleh beberapa orang yang tergabung dalam suatu kelompok untuk saling bertukar pendapat tentang suatu masalah atau bersama-sama mencari pemecahan untuk mendapatkan jawaban dan kebenaran atas suatu masalah. Pemanfaatan diskusi mempunyai arti yang sangat penting. Guru yang satu dengan yang lainnya saling bertukar pendapat dalam pengembangan Silabus dan Rencana Pelaksanaan Pembelajaran di sekolah.

\section{Mengikuti Pelatihan, Workshop, dan Penataran}

Guru dalam pengembangan silabus dan Rencana Pelaksanaan Pembelajaran diawali dengan mengikuti pelatihan, workshop dan penataran yang diselenggarakan oleh Departemen Pendidikan Nasional. Kebijakan Departemen Pendidikan Nasional memfasilitasi penyusunan silabus dengan membentuk sebuah tim yang terdiri dari para guru yang memiliki pengalaman dalam penyusunan silabus (BSNP,2006:15).

Penyusunan silabus dilaksanakan bersama-sama pada musyawarah guru mata pelajaran (MGMP) pada tingkat satuan pendidikan untuk satu ssekolah atau 
kelompok sekolah dengan tetap memperhatikan karakteristik masing-masing sekolah. Prinsip yang mendasari pengembangan silabus antara lain :

1) Ilmiah yaitu keseluruhan materi dan kegiatan yang menjadi muatan dalam silabus harus benar dan dapat dipertanggungjawabkan secara keilmuwan. Untuk mencapai kebenaran ilmiah tersebut, dalam penyusunan silabus selayaknya dilibatkan para pakar dibidang keilmuwan masing-masing mata pelajaran. Hal ini dimaksudkan agar materi pelajaran yang disajikan dalam Silabus (Valid).

2) Relevan yaitu cakupan, kedalaman, tingkat kesukaran dan urutan penyajian materi dalam silabus sesuai atau ada keterkaitan dengan tingkat perkembangan fisik, intelektual, sosial, emosional, dan spiritual peserta didik.

3) Sistematis yaitu komponen-komponen silabus saling berhubungan secara fungsional dalam mencapai kompetensi.

4) Konsisten yaitu adanya hubungan yang konsisten antara kompetensi dasar, indikator, materi pokok, pengalaman belajar, sumber belajar, dan sistem penilaian.

5) Memadai yaitu cakupan indikator, materi pokok, pengalaman belajar, sumber belajar, dan sistem penilaian cukup untuk menunjang pencapaian kompetensi dasar.

6) Aktual dan kontekstual yaitu cakupan indikator, materi pokok, pengalaman belajar, sumber belajar dan sistem penilaian memperhatikan perkembangan ilmu, teknologi dan seni mutakhir dalam kehidupan nyata, dan peristiwa yang terjadi.

7) Fleksibel yaitu keseluruhan komponen silabus dapat mengakomodasi keragaman peserta didik, pendidik, serta dinamika perubahan yang terjadi disekolah dan tuntutan masyarakat.

8) Menyeluruh yaitu komponen silabus mencakup keseluruhan ranah kompetensi(kognitif, afektif, psikomotor) (Masnur Muslich,2007:26)

Silabus bermanfaat sebagai pedoman dalam pengembangan pembelajaran lebih lanjut, seperti pembuatan rencana pembelajaran, pengelolaan kegiatan pembelajaran, dan pengembangan sistem penilaian. Silabus bermanfaat sebagai pedoman untuk merencanakan pengelolaan kegiatan pembelajaran. Misalnya 
kegiatan pembelajaran secara klasikal, kelompok kecil atau pembelajaran secara individual. Silabus juga sangat bermanfaat untuk mengembangkan sistem penilaian. Sistem penilaian selalu mengacu pada standar kompetensi, kompetensi dasar, dan materi pokok/pembelajaran yang terdapat dalam Silabus. Hal tersebut sesuai dengan pembelajaran berbasis kompetensi.

\section{Menyediakan Sarana dan Prasarana}

Kinerja guru dalam pengembangan silabus, dan Rencana Pelaksanaan Pembelajaran diawali dengan upaya menyediakan sarana dan prasarana. Muhamad Joko Susilo (2007:65) menyebutkan sarana adalah peralatan dan yang secara langsung dipergunakan dalam proses pendidikan, sedangkan prasarana adalah fasilitas yang secara tidak langsung menunjang jalannya proses pendidikan atau pengajaran.

Dalam pengembangan silabus, dan Rencana Pelaksanaan Pembelajaran sarana dan prasarana yang diperlukan adalah tempat, buku acuan, buku-buku pelajaran, jurnal, kalender pendidikan, brosur. Semua sumber tersebut menunjukkan seluruh katagori aktifitas pendidikan selama satu tahun dan dirinci dalam semesteran, bulanan dan mingguan.

\section{SIMPULAN}

Langkah-langkah pengembangan silabus dan Rencana Pelaksanaan Pembelajaran Agama Hindu adalah 1) langkah pengembangan silabus yaitu mengisi identitas, mengkaji standar kompetensi, mengkaji dan menentukkan kompetensi dasar, mengidentifikai maslah pokok, mengembangkan pengalaman belajar, merumuskan indikator pencapaian kompetensi, menentukan jenis penilaian, alokasi waktu, dan menentukan sumber belajar, 2) langkah pengembangan Rencana Pelaksanaan Pembelajaran yaitu mengisi identitas, menentukan alokasi waktu, menentukan standar kompetensi dan kompetensi dasar serta indikator, merumuskan tujuan pembelajaran, mengidentifikasi materi pokok menentukan metode pembelajaran, merumuskan langkah-langkah pembelajaran, menentukan sumber belajar, dan menyusun kriteria penilaian. 
Faktor pendorong dalam pengembangan silabus dan Rencana Pelaksanaan Pembelajaran Agma Hindu adalah minat terhadap tugas, tanggung jawab terhadap tugas, sarana dan prasarana, perhatian dari kepala sekolah.

Upaya pengembangan silabus dan Rencana Pelaksanaan Pembelajaran Agama Hindu adalah melakukan diskusi dengan guru yang berpengalaman, mengikuti pelatihan, workshop, penataran yang penyelenggaraannya dilakukan oleh Departemen Pendidikan Nasional yang terkait dengan pengembangan silabus dan Rencana Pelaksanaan Pembelajaran pada Kurikulum Tingkat Satuan Pendidikan, serta menyediakan sarana dan prasarana yang dipergunakan dalam pengembangn silabus dan Rencana Pelaksanaan Pembelajaran Agama Hindu berupa buku pedoman dan teknologi pendidikan.

\section{DAFTAR PUSTAKA}

Badan Standar Nasional Pendidikan (BNSP). 2006. Panduan Penyusunan Kurikulum Tingkat Satuan Pendidikan Dasar dan Menengah.

Dakir. 2004. Perencanaan dan Pengembangan Kurikulum. Jakarta: Rineka Cipta.

Departemen Pendidikan Nasional. 2003. Kurikulum Berbasis Kompetensi Mata Pelajaran Agama Hindu Sekolah Menengah Atas. Jakarta

Muhammad Joko Susilo. 2007. Kurikulum Tingkat Satuan Pendidikan. Yogyakarta: Pustaka Belajar.

Mulyasa, 2007. Kurikulum Tingkat Satuan Pendidikan. Bandung: PT. Remaja

Slameto.2003. Belajar dan Faktor-faktor yang mempengaruhinya. Jakarta: Rineka Cipta

Standar Nasional Pendidikan (SNP). 2006. Jakarta: Asa Mandiri

Trianto. 2007. Model-Model Pembelajaran Inovatif Berorientasi Konstruktivistik Jakarta : Prestasi Pustaka 
